\title{
Advanced Techniques for Securing Airway in Mucopolysaccharidoses and the Impact of New Therapeutic Approaches
}

\author{
Yousef M. Mohammed ${ }^{1,2}$, Safeera Khan ${ }^{3}$
}

1. Anesthesia and Pain Management, California Institute of Behavioral Neurosciences \& Psychology, Fairfield, USA 2. Medicine, Damascus University, Damascus, SYR 3. Internal Medicine, California Institute of Behavioral Neurosciences \& Psychology, Fairfield, USA

Corresponding author: Yousef M. Mohammed, yousefmoemoe@gmail.com

\begin{abstract}
Airway management in patients suffering from mucopolysaccharidoses (MPS) is one of the most difficult anesthesiologic challenges. MPS is a group of rare, inherited diseases caused by the absence or malfunctioning of lysosomal enzymes needed to break down macromolecules called glycosaminoglycans (GAGs). MPS is associated with clinical symptoms and physical features, which all together contribute to the high incidence of difficulty in providing airway during surgical procedures. We used PubMed as our main database (PubMed Advanced Search Builder) to search for relevant literature. At first, we looked for the prevalence of MPS worldwide. Then, we searched for airway management complications in the MPS population using the keywords: "Mucopolysaccharidoses," "Anesthesia complications," and "airway management." Another search was carried out to look for new therapeutic agents and explore their impacts on body organs. We reviewed the finalized articles to explore how anesthesiologists used different airway techniques. We discovered that video laryngoscope and I-gel aided fiber-optic intubation have been available in recent years and have been used uneventfully in several patients. We presented recommendations regarding preoperative and intraoperative preparation to avoid airway-related complications in the future. We realized that many therapy approaches had been suggested, especially after further understanding of the pathophysiology of MPS. However, more investigation needs to be conducted to determine their efficacy and explore if there is any impact on airway management.
\end{abstract}

Received 08/31/2020

Review began 09/10/2020 Review ended 09/20/2020 Published 09/22/2020

() Copyright 2020

Mohammed et al. This is an open access article distributed under the terms of the Creative Commons Attribution License CC-BY 4.0., which permits unrestricted use, distribution, and reproduction in any medium, provided the original author and source are credited.
Categories: Anesthesiology, Endocrinology/Diabetes/Metabolism, General Surgery

Keywords: anesthesia complications, mucopolysaccharidoses, airway techniques, new therapy approaches

\section{Introduction And Background}

The global prevalence of all types of MPS has been one case in 25,000 births [1]. Data collected from two studies, one conducted in Japan between 1982 and 2009 and other in Switzerland between 1975 and 2008, showed 41 patients with MPS were identified in Switzerland, and 467 patients were identified in Japan making a combined birth prevalence of 1.56 and 1.53 per 100,000 live births, respectively [2]. MPS is a group of inherited metabolic diseases caused by genetic defects in the production of the lysosomal enzymes that degrade glycosaminoglycans (GAGs), previously known as mucopolysaccharidoses (MPS). Accumulation of GAGs in various tissues and organs is associated with a progressive decline in organ function and considerable tissue damage. All MPS are inherited in an autosomal recessive pattern, which affects males and females equally, whereas the only one inherited as an X-recessive disorder is MPS II, which affects only males [3]. Table 1 shows the classification of different MPS diseases and the enzymes deficient in them. 


\section{Cureus}

\section{Mucopolysaccharidoses Disease \\ Mucopolysaccharidoses I: IH as Hurler syndrome, IH/S as Hurler-Scheie syndrome, and IS as Scheie syndrome \\ Mucopolysaccharidoses II: Hunter syndrome \\ Mucopolysaccharidoses III A-D: Sanfilippo syndrome}

Mucopolysaccharidoses IV A, B: Morquio syndrome

Mucopolysaccharidoses VI: MaroteauxLamy syndrome

Mucopolysaccharidoses VII: Sly syndrome

Mucopolysaccharidoses IX

Hyaluronidase 1

Mucopolysaccharidoses V and VIII terms are no longer used.

\section{Deficient Enzyme}

a-L-iduronidase

Iduronate sulfate sulfatase
Accumulated

Glycosaminoglycans

Dermatan sulfate, Heparan sulfate

Dermatan sulfate, Heparan sulfate glucosaminidase, C: Acetyl-Co-A glucosaminidase, D: Heparan sulfate $\mathrm{N}$-Acetylglucosidase $\mathrm{N}$-acyltransferase

A: Galactosamine-6-sulfate sulfatase, B: Galactosamine-6-sulfate sulfatase

A: Keratan sulfate, Chondroitin 6-sulfate; B: Keratan sulfate, Chondroitin 6-sulfate

$\mathrm{N}$-acetyl-galactosamine a-4-sulfate sulfatase Dermatan sulfate

Dermatan sulfate, Heparan sulfate, Chondroitin sulfate

Hyaluronan

TABLE 1: Classification of Mucopolysaccharidoses With the Deficient Enzymes and the Accumulated Glycosaminoglycans

Patients usually are healthy at birth, and the pathological manifestations like involvement of respiratory, cardiac, and joint systems; organ enlargement; coarsened facial features; skeletal abnormalities; nose and throat problems; and mental retardation occur later in life [3-5]. Various potential problems with MPS patients related to the accumulation of GAGs in the respiratory airways can cause hypertrophy of adenoids, tonsils, and laryngopharynx, which in turn can make anesthetic airway very difficult [6]. MPS patients undergo surgeries for different organ involvement. A study including 527 patients with MPS II showed that 83.7\% of patients needed a surgical intervention during disease progression [7]. Umbilical and inguinal hernia repair, myringotomies and related procedures, tracheostomy, nasal and sinus procedures, spinal surgeries, cardiac valve replacement, orthopedic surgery, adenotonsillectomy, abdominal interventions, and oral surgery are usually the most common required surgeries for patients with MPS I and are prevalent in other MPS types too $[8,9]$. Other risk factors causing a difficult airway access include hypoplastic tracheal cartilages as well as restrictive lung disease and stiff temporomandibular joints, which altogether can make laryngoscopy and endotracheal tube placement very difficult and can even become worse by increased oral and nasal secretions [10]. Also, facemask difficulties have been reported for different reasons such as anatomical issues, oral and nasal secretions, or even mucosal swelling after intubation $[11,12]$. The purpose of this paper is to review the previous literature and find out why MPS patients represent a big challenge for anesthesiologists. We will try to look at other anesthesiologists' experiences, investigate the recent techniques, provide a guideline of recommendations regarding airway management, and explore if there is any impact of new suggested MPS treatments on airway obtaining.

\section{Review}

The study aimed to examine the anesthesiologic complications related to airway management in MPS patients. We carried out our search using PubMed as our main database (PubMed Advanced Search Builder). First, we looked for the epidemiology of MPS worldwide, and then we used a combination of the following terms: "Mucopolysaccharidoses," "Anesthesia complications," and "airway management". Another search was conducted specifically to investigate the recent MPS treatments. The search included all ages and was limited to the articles available in the English language and involved the studies on human subjects only. Prospective studies and randomized controlled trials were lacking regarding the evidence base for airway management. Preferred Reporting Items for Systematic Reviews and Meta-Analyses (PRISMA) guidelines were not used in our traditional review. A full-quality appraisal of all the collected studies was not done. We selected our studies after screening the articles by going through the titles and abstracts to find the relevant literature on the topic of interest. Among the selected studies, there were three clinical trials regarding new MPS therapy approaches that have not been published yet. Also, additional studies were added when bibliographic references of identified articles were reviewed to find articles not identified by electronic search. The collection of the articles for this study was done ethically and legally. 


\section{Airway management risk factors}

MPS diseases are a group of gradually progressive diseases, with a significant influence on the quality of life. Many MPS patients require surgical interventions during disease advancement. MPS is associated with both clinical and physical challenges (Figure 1) that can lead to serious difficulties regarding airway management [3-6,10]. A study showed that while undergoing surgery, nearly $20 \%$ of deaths with MPS I patients were directly associated with airway complications [8]. A retrospective study of 31 patients with mixed MPS types evaluated upper and lower airway findings on flexible bronchoscopy while undergoing anesthetic procedures and reported that the most common features were GAGs deposit in the upper airways in $72 \%$, laryngomalacia in $31 \%$, and lower airway deposits in $46 \%$ [13]. All these findings can seriously endanger patients' lives during anesthesia. Figure 1 shows the difficulties encountered during anesthesia administration of MPS patients.

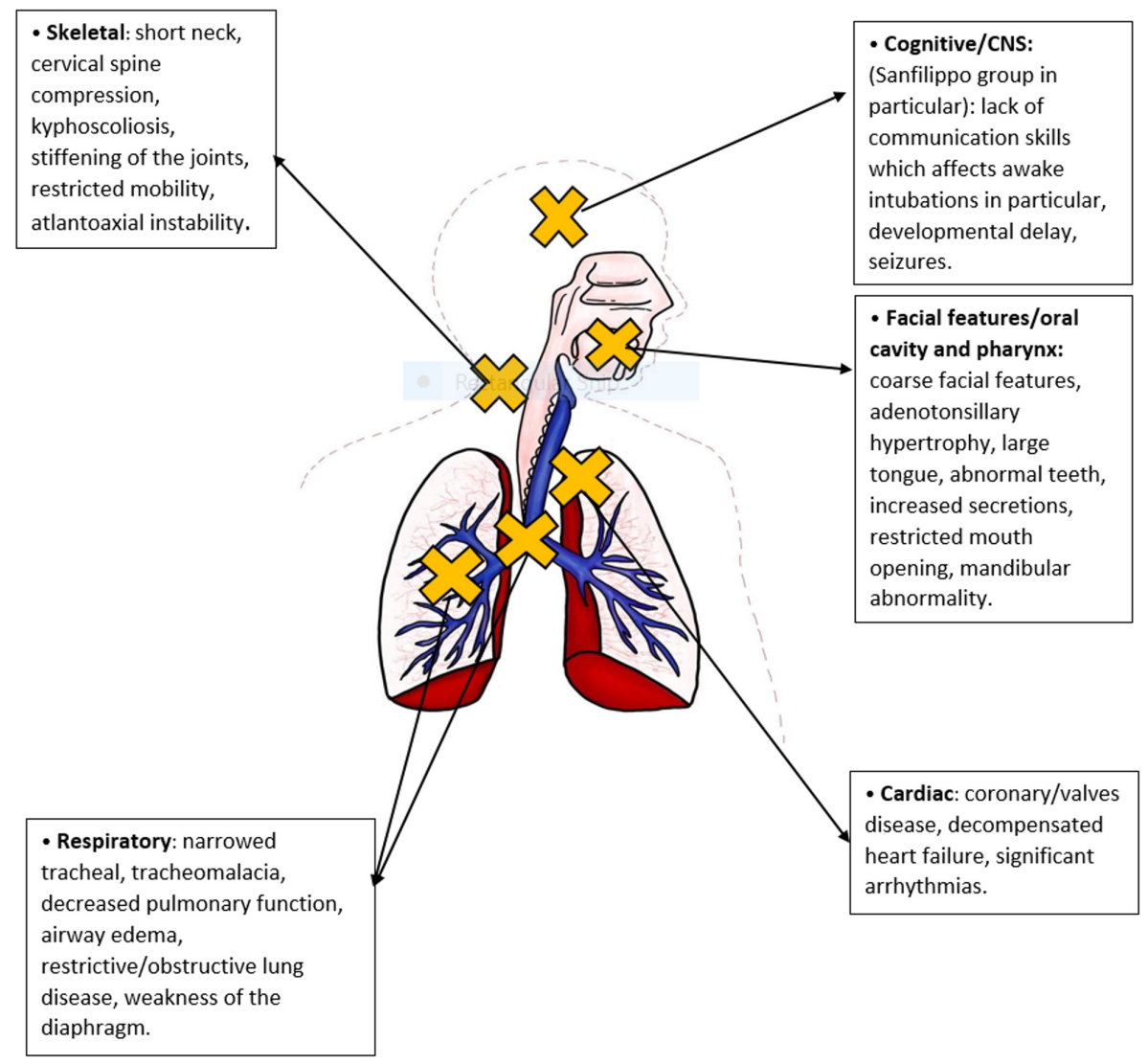

\section{FIGURE 1: Difficulties in Anesthesia Administration of Mucopolysaccharidoses}

\section{Descriptions of difficult airways in MPS patients}

In the selected case series, we discovered the incidence of difficult airways during the anesthetic procedures in mixed MPS patients from different age groups. Two case series reported difficult face mask placement in 20 out of 141 procedures and 11 out of 44 procedures [11,14]. The overall rate of difficult face mask in two series of different MPS types varies between $6.7 \%$ and $33.3 \%[15,16]$. Furthermore, a retrospective analysis of 54 MPS patients showed that intubation was performed in 65 out of 232 anesthetic procedures (28\%), added that 19 intubations (29.2\%) among those were considered difficult (a Cormack and Lehane score of three or more), and showed that there is a link between older age and increased rates of difficult airways without any association with MPS type [17]. Patients from older age groups would have more anatomical alterations than younger groups. The lack of association between MPS type and airway problems can be due to the inadequate number of patients with specific MPS types. Some studies concluded that higher age is associated only with difficult intubation. In contrast, any difficulty in the placement of either face mask or laryngeal mask airway is not associated with more senior ages [18].

On the other hand, two case series linked difficult intubation to both MPS type and higher age $[11,14]$. Also, two reviews of a large number of MPS III patients revealed no difficulties with mask ventilation and tracheal intubation $[19,20]$. The lack of problems regarding mask ventilation and tracheal intubation in MPS III 
patients means that the level of difficult airways differs among MPS types. It is probably due to the severe somatic involvement in some MPS types and the milder or no involvement in others, particularly MPS III. The overall frequency of difficult endotracheal intubation, including the failed attempts in several series regardless of MPS types, is between $3.17 \%$ and $44.2 \%[11,12,14,19]$. The results of the reviewed series are summarized in Table 2 .

\begin{tabular}{|c|c|c|c|c|}
\hline Name & $\begin{array}{l}\text { Year of } \\
\text { Publication }\end{array}$ & $\begin{array}{l}\text { Number } \\
\text { of } \\
\text { Patients }\end{array}$ & $\begin{array}{l}\text { Number of } \\
\text { Anesthetics }\end{array}$ & Airway Management Results \\
\hline $\begin{array}{l}\text { Frawley } \\
\text { et al. [11] }\end{array}$ & 2012 & $\begin{array}{l}17 \text { mixed } \\
\text { types }\end{array}$ & 141 & $\begin{array}{l}\text { Difficult face mask placement was observed in } 14.81 \% \text { of cases ( } 20 \text { anesthetics). } \\
\text { Difficult intubation was seen in } 28 \% \text { of cases ( } 40 \text { procedures). }\end{array}$ \\
\hline $\begin{array}{l}\text { Walker } \\
\text { et al. [12] }\end{array}$ & 1994 & $\begin{array}{l}34 \text { mixed } \\
\text { types }\end{array}$ & 89 & $\begin{array}{l}\text { Eight patients developed a problem regarding face mask usage (six patients due } \\
\text { to anatomical issues and two patients due to excess secretions). Tracheal } \\
\text { intubation was conducted on } 60 \text { occasions ( } 29 \text { patients); it was difficult on } 20 \\
\text { occasions ( } 33.3 \%) \text {. Laryngeal mask airway was used on } 12 \text { occasions and was } \\
\text { used three times in one patient after a failed intubation. }\end{array}$ \\
\hline $\begin{array}{l}\text { Moores } \\
\text { et al. [14] }\end{array}$ & 1996 & $\begin{array}{l}28 \text { mixed } \\
\text { types }\end{array}$ & 99 & $\begin{array}{l}\text { Face mask was used in } 44 \text { procedures and was difficult to use in } 11 \text { procedures } \\
(25 \%) \text {. Intubation was conducted } 52 \text { times with } 23 \text { difficult intubations. Laryngeal } \\
\text { mask airway was used in two procedures. }\end{array}$ \\
\hline $\begin{array}{l}\text { Megens } \\
\text { et al. [15] }\end{array}$ & 2014 & $\begin{array}{l}19 \text { mixed } \\
\text { types } \\
\text { (including } \\
17 \text { Hurler } \\
\text { patients) }\end{array}$ & 136 & $\begin{array}{l}\text { tracheal intubation was found in } 24 \text { out of } 67 \text { cases, video laryngoscope was } \\
\text { successful in } 89 \% \text {, direct laryngoscope was successful in } 67 \% \text {, and fiber-optic } \\
\text { scope was uncomplicated in } 20 \% \text {. }\end{array}$ \\
\hline BM et al. & 2017 & $\begin{array}{l}18 \text { mixed } \\
\text { types }\end{array}$ & 49 & $\begin{array}{l}\text { Two out of six patients had difficult mask ventilation. Difficult intubation was seen } \\
\text { in three out of } 36 \text { occasions ( } 8.3 \%) \text { and was conducted either via fiber-optic } \\
\text { intubation or video laryngoscope in } 15 \text { procedures. Video laryngoscope was able } \\
\text { to secure native airways uneventfully in } 12 \text { out of } 18 \text { patients. However, it could } \\
\text { not keep a glottic view in one patient, so synchronous use of video laryngoscope } \\
\text { and fiber-optic intubation was conducted. }\end{array}$ \\
\hline $\begin{array}{l}\text { Scaravilli } \\
\text { et al. [17] }\end{array}$ & 2018 & $\begin{array}{l}54 \text { mixed } \\
\text { types }\end{array}$ & 232 & $\begin{array}{l}\text { Face mask ventilation was conducted in } 167 \text { cases }(72 \%) \text {; in three cases, it was } \\
\text { inadequate. Intubation was used in } 65 \text { procedures and was difficult in } 29 \% \text { of } \\
\text { them. }\end{array}$ \\
\hline $\begin{array}{l}\text { Cohen et } \\
\text { al. [19] }\end{array}$ & 2017 & $\begin{array}{l}34 \\
\text { sanfilippo } \\
\text { patients }\end{array}$ & 86 & $\begin{array}{l}\text { Mask ventilation was easy in all patıents. Endotracheal intubation was used in } \\
73.2 \% \text { of cases ( } 63 \text { occasions). Of those, two were seen difficult. }\end{array}$ \\
\hline $\begin{array}{l}\text { Kamata } \\
\text { et al. [20] }\end{array}$ & 2017 & $\begin{array}{l}25 \\
\text { sanfilippo } \\
\text { patients }\end{array}$ & 43 & $\begin{array}{l}\text { No difficulties in mask ventilation during the procedures. Upper airway } \\
\text { obstruction was seen in } 14 \text { procedures ( } 33 \%) \text { and was managed easily with } \\
\text { continuous positive airway pressure, temporary oral airway placement, and jaw } \\
\text { thrust. A small shoulder roll was required for } 11 \text { cases }(26 \%) \text {. Tracheal intubation } \\
\text { was not conducted. }\end{array}$ \\
\hline
\end{tabular}

TABLE 2: Airway Management Results in Mucopolysaccharidoses Case Series

\section{Recent vs previous techniques}

Despite all the problems associated with airway management in the MPS population, many cases have been secured successfully $[1,21,22]$. Using a supraglottic device to aid fiber-optic intubation can be very useful in MPS patients. Laryngeal mask airway, which is, a previous accessible device, has facilitated fiber-optic intubation in many patients adequately $[11,12,15,17]$. However, laryngeal mask airway should be used with caution in patients with high larynx and may be difficult to insert for patients who cannot open their mouths adequately [14,23]. I-gel is a recently presented supraglottic device that has been a perfect choice on many occasions [24-26]. I-gel has been reported as the best supraglottic device to facilitate intubation when it was compared with other supraglottic devices [26]. However, I-gel may not be appropriate for all mouth sizes [25]. Intubation using video laryngoscope has been in use only in recent years as a substitute intubation technique, and since it had been introduced, many MPS cases were intubated with no problems [15-19]. Tracheal intubation of MPS patients using video laryngoscope is superior to the use of either direct laryngoscopy or fiber-optic scope [15]. Direct laryngoscopy has been complicated even with many attempts 


\section{Cureus}

[27]. However, video laryngoscope was not able to provide adequate vision in some cases, and fiber-optic scope was used instead [28]. Access to all the newly and previously introduced devices must be available to avoid any unexpected events. After more evidence regarding video laryngoscope superiority would be presented, the worldwide handiness of this newer and quicker technique will make it a preferred method in MPS patients who may no more develop complications regarding intubation placement. Another benefit of these recent techniques is decreasing the necessity for tracheostomy in MPS patients [11,12]. Avoiding tracheostomy in MPS is always a better choice due to the anatomical changes during the progression of the disease. However, the necessity of tracheostomy was mandatory in some cases [1]. A summary of the studies showing an overview of use of various techniques in MPS patients is shown in Table 3.

\begin{tabular}{|c|c|c|c|c|}
\hline $\begin{array}{l}\text { Author } \\
\text { Name/Year } \\
\text { of } \\
\text { Publication }\end{array}$ & $\begin{array}{l}\text { Disease } \\
\text { Type }\end{array}$ & $\begin{array}{l}\text { Surgery/Age } \\
\text { (years) }\end{array}$ & Clinical and Physical Features & Airway Securing \\
\hline $\begin{array}{l}\text { Hack et al. } \\
2016[1]\end{array}$ & $\mathrm{IH} / \mathrm{S}$ & $\begin{array}{l}\text { C1-4 } \\
\text { laminectomy } \\
\text { and } \\
\text { occipitocervical } \\
\text { fusion (C0-C5) } \\
\text { for cervical } \\
\text { stenosis/27 }\end{array}$ & $\begin{array}{l}\text { Signs of cervical myelopathy, limited } \\
\text { neck movement, severe micrognathia, } \\
\text { severe obstructive sleep apnea, } \\
\text { restrictive lung disease }\end{array}$ & $\begin{array}{l}\text { Awake fiber-optic intubation was done. In the } \\
\text { end, tongue and lip swelling was noted. The } \\
\text { patient was extubated on postoperative day } \\
\text { two. }\end{array}$ \\
\hline $\begin{array}{l}\text { Hack et al. } \\
2016 \text { [1] }\end{array}$ & $\mathrm{IH} / \mathrm{S}$ & $\begin{array}{l}\text { Mitral valve } \\
\text { replacement/25 }\end{array}$ & $\begin{array}{l}\text { The patient had become breathless } \\
\text { due to untreated severe mitral } \\
\text { stenosis. Later, mitral regurgitation } \\
\text { with pulmonary hypertension occurred. }\end{array}$ & $\begin{array}{l}\text { Fiber-optic intubation was conducted } \\
\text { successfully. After the surgery was done, the } \\
\text { patient underwent a tracheostomy (to facilitate } \\
\text { any prolonged period of ventilation if required). } \\
\text { The patient called for five days of postoperative } \\
\text { ventilator support. Weeks later, the patient } \\
\text { made a good recovery. }\end{array}$ \\
\hline $\begin{array}{l}\text { Hack et al. } \\
2016 \text { [1] }\end{array}$ & II & ENT surgery/18 & $\begin{array}{l}\text { Hoarse voice, difficulty in breathing, } \\
\text { and subsequent choking on eating. } \\
\text { Severe obstructive sleep apnea with } \\
\text { daytime somnolence. A CT scan of his } \\
\text { thorax showed a twisting trachea with } \\
\text { a narrowing in the subglottic and distal } \\
\text { tracheal regions. }\end{array}$ & $\begin{array}{l}\text { Awake fiber-optic intubation was done. } \\
\text { Tracheostomy was conducted despite the } \\
\text { anatomical difficulties. The patient was } \\
\text { discharged home after two months. }\end{array}$ \\
\hline $\begin{array}{l}\text { Kadic et al. } \\
2012 \text { [21] }\end{array}$ & IV & $\begin{array}{l}\text { Total hip } \\
\text { replacement/31 }\end{array}$ & $\begin{array}{l}\text { Pain on the hips, deformity of the joints } \\
\text { with bilateral coxarthrosis. The patient } \\
\text { had a large head, short neck, large } \\
\text { tongue, and abnormal shape of the } \\
\text { spine on the radiograph }\end{array}$ & $\begin{array}{l}\text { Awake fiber-optic intubation was conducted } \\
\text { successfully, followed by awake extubation. }\end{array}$ \\
\hline $\begin{array}{l}\text { McLaughlin } \\
\text { et al. } 2010 \\
\text { [22] }\end{array}$ & IV & $\begin{array}{l}\text { Total hip } \\
\text { replacement/26 }\end{array}$ & $\begin{array}{l}\text { The patient had short stature, with a } \\
\text { large head, short neck, macroglossia, } \\
\text { enlarged uvula and tonsils. Kyphosis, } \\
\text { anterior beaking of the cervical } \\
\text { vertebrae on a radiograph and barrel } \\
\text { chest were also noticed. The patient } \\
\text { was diagnosed with osteoarthritis of } \\
\text { the hips secondary to avascular } \\
\text { necrosis. }\end{array}$ & $\begin{array}{l}\text { Awake fiber-optic intubation was conducted. } \\
\text { The trachea was extubated awake, and recovery } \\
\text { was uncomplicated. }\end{array}$ \\
\hline \multirow[t]{2}{*}{$\begin{array}{l}\text { Michalek et } \\
\text { al. } 2008[24]\end{array}$} & II & $\begin{array}{l}\text { Dental } \\
\text { procedure } \\
\text { under general } \\
\text { anesthesia, } \\
\text { which included } \\
\text { radiographs, } \\
\text { cleaning, } \\
\text { polish, five } \\
\text { fillings, and four } \\
\text { extractions/25 }\end{array}$ & $\begin{array}{l}\text { Snoring at night, sleep apnea, } \\
\text { dysphagia, gastric reflux with repeated } \\
\text { aspiration cases of pneumonia, otitis } \\
\text { media, multiple organs enlargement. } \\
\text { The thyromental distance was } 5.5 \mathrm{~cm} \text {; } \\
\text { neck mobility was extremely limited; } \\
\text { and big tongue, and small mandible } \\
\text { were also noted. }\end{array}$ & $\begin{array}{l}\text { Mask ventilation was difficult, and a size- } 4 \text { l-gel } \\
\text { was inserted at the first attempt. Mechanical } \\
\text { ventilation with an I-gel was effective in guiding } \\
\text { the fiber-optic scope. General anesthesia lasted } \\
\text { for } 130 \text { min. The postoperative period was } \\
\text { uneventful, and the patient was dismissed the } \\
\text { same day. }\end{array}$ \\
\hline & & & & Fiber-optic bronchoscope was introduced \\
\hline
\end{tabular}




\begin{tabular}{|c|c|c|c|c|}
\hline $\begin{array}{l}\text { Dhanger et } \\
\text { al. } 2015 \text { [25] }\end{array}$ & IV & $\begin{array}{l}\text { Fixation of } \\
\text { atlantoaxial } \\
\text { subluxation/3 }\end{array}$ & $\begin{array}{l}\text { A weakness of lower extremities, } \\
\text { coarse facies, macroglossia, large } \\
\text { head, short neck, barrel chest, } \\
\text { scoliosis, hyperreflexia, atlantoaxial } \\
\text { subluxation, and rotation of C2 over } \\
\text { C1 }\end{array}$ & $\begin{array}{l}\text { through the I-gel into the trachea, and then the } \\
\text { endotracheal tube was inserted, followed by } \\
\text { removal of the bronchoscope and l-gel. Airway } \\
\text { edema was noted, so the patient was moved to } \\
\text { the intensive care unit. The child was extubated } \\
\text { on the first postoperative day and discharged } \\
\text { home on the eighth postoperative day. }\end{array}$ \\
\hline $\begin{array}{l}\text { Sayilgan et } \\
\text { al. } 2012 \text { [27] }\end{array}$ & $\mathrm{VI}$ & $\begin{array}{l}\text { Mitral valve } \\
\text { replacement } \\
\text { surgery/9 }\end{array}$ & $\begin{array}{l}\text { The patient suffered from dyspnea due } \\
\text { to mitral valve prolapse and severe } \\
\text { insufficiency. Physical examination } \\
\text { showed microcephaly, coarse face, } \\
\text { macroglossia, corneal opacity, gum } \\
\text { hypertrophy, short neck, and } \\
\text { kyphoscoliosis. }\end{array}$ & $\begin{array}{l}\text { Intubation via direct laryngoscopy was } \\
\text { unsuccessfully attempted four times. The patient } \\
\text { was successfully intubated on the fifth attempt, } \\
\text { and ventilation via mask was sufficient between } \\
\text { intubation attempts. }\end{array}$ \\
\hline $\begin{array}{l}\text { Tsuchiya et } \\
\text { al. } 2019 \text { [28] }\end{array}$ & $\begin{array}{l}\text { (a) I, (b) } \\
\text { II, (c) II, } \\
\text { (d) I, (e) } \\
\text { II, (f) VII }\end{array}$ & $\begin{array}{l}\text { I) Scoliosis } \\
\text { correction/28, } \\
\text { all other } \\
\text { patients had } \\
\text { cervical } \\
\text { decompression } \\
\text { and their ages } \\
\text { ranged } \\
\text { between } 13 \\
\text { and } 38\end{array}$ & $\begin{array}{l}\text { Short neck with limited mobility, } \\
\text { inability to fully open the mouth linked } \\
\text { with macroglossia, abnormal } \\
\text { enlargement of the epiglottis, arytenoid } \\
\text { region, abnormal gate, limb weakness, } \\
\text { compression of the spinal cord and } \\
\text { disappearance of the normal curvature. }\end{array}$ & $\begin{array}{l}\text { Face mask was difficult in two patients. Tracheal } \\
\text { intubation was performed within } 18 \text { minutes in } \\
\text { all six patients without a significant decrease in } \\
\text { arterial oxygen saturation. Awake or under } \\
\text { anesthesia fiber-optic intubation and video } \\
\text { laryngoscope were used successfully. None } \\
\text { exhibited airway edema or severe obstruction } \\
\text { upon extubation. }\end{array}$ \\
\hline \multicolumn{5}{|c|}{ TABLE 3: Various Airway Management Techniques in Mucopolysaccharidoses Patients } \\
\hline \multicolumn{5}{|c|}{ Practice recommendations for airway management in MPS } \\
\hline \multicolumn{5}{|c|}{$\begin{array}{l}\text { Although the level of advantage for a particular technique cannot be specified from the literature, there is } \\
\text { sufficient understanding between anesthesiologists that a preformed strategy can lead to better results. The } \\
\text { aim of these recommendations (Table } 4 \text { ) is to prepare anesthesiologists to avoid airway-related problems in } \\
\text { MPS patients. These recommendations that yield basic advice based on current published literature }[3,6,29- \\
31] \text { can be revised and amended depending on clinical demands. However, it cannot warrant any particular } \\
\text { consequence, and many patients may require additional assessment tools to figure out the nature of the } \\
\text { predicted airway problem. Table } 4 \text { shows some recommendations for anesthesiologists for securing airway in } \\
\text { MPS patients. }\end{array}$} \\
\hline
\end{tabular}

Preoperative Evaluation

All previously conducted anesthetic procedures must be reviewed. Physical airway examination and CT scan of the airway would be preferable. Radiographic evaluation to rule out any atlantoaxial subluxation. Assessment of sleep disorders and cardiorespiratory function is mandatory. At least, one additional individual must be available to help for unpredicted difficult airways.

\section{Airway Securing Comments}

Specialized equipment for airway management, including supraglottic devices and suitable tubes sizes, must be available. The correct position of the patient must be secured with stabilization of the neck. Consider under anesthesia or awake intubation. Confirm endotracheal tube placement. Intraoperative neurophysiologic assessment to predict spinal compression occurrence.

\section{TABLE 4: Recommendations for Anesthesiologists}

\section{The impact of new MPS treatments on airway management}

Recently, the quality of life in patients with lysosomal storage diseases, including MPS, has improved noticeably due to the remarkable development that has been reached in the field of therapy. Enzyme replacement therapy (ERT) and hematopoietic stem cell transplantation (HSCT) have been the standard of care in the MPS population. However, there is no satisfactory evidence regarding the impact of these treatments on reducing the anesthesiological risks. Two retrospective studies reported that treatment with ERT alone in MPS patients did not decrease the rate of difficult airways. At the same time, HSCT reduced the incidence of difficult mask ventilation and difficult endotracheal intubation when conducted at younger ages before the progression of the disease [11,32]. This can be due to the lack of a sufficient amount of ERT taken 
On the other hand, a recent study showed no difference in airway management in patients who received HSCT and those who did not [18]. Also, HSCT has been associated with a high mortality rate [32]. ERT, followed by HSCT, could not lead to uneventful airway management in a retrospective report [15]. It has been evident that ERT has an insufficient influence on some vital organs such as bones, heart, and valves [33]. The inability of the ERT to cross the blood-brain barrier to curing the spinal cord compression and neurocognitive deterioration has made its impact more limited [3,33]. Significant restrictions regarding high mortality rate (HSCT), limited impact on vital organs (ERT), and the expenses issue have all together pushed toward finding more effective and better therapeutic methods. Further understanding of the pathophysiology of MPS has helped researchers to go beyond the points already reached regarding therapy agents. Some studies have offered enough proof that lysosomes are not there only to break down large molecules, but they can be engaged in many additional pathways such as signaling, adaptive immunity, plasma membrane trafficking, metabolism, and growth issues [34]. This broad involvement of lysosomes in several processes can contribute to difficult airways in MPS. Recently, some studies have investigated many therapeutic approaches, and some of them are promising. One approach was the recognition of all enzymes and processes involved in the formation of GAGs, which led to the development of substrate reduction therapy (SRT) [33]. SRT was able to decrease the level of GAGs deposits, improve the elasticity of connective tissues, and enhance the joints motion in MPS patients [35]. GAGs accumulation would no more be problematic whenever airways would be secured in MPS patients if enough studies would conclude the impacts of SRT. Unpredicted influence of GAGs deposits in MPS is the activation of the inflammation pathway, which can contribute to the pathological background to some of the disease manifestations such as skeletal abnormalities and nerve involvement [33]. Anti-tumor necrosis factor-alpha (anti-TNF $\alpha$ ) has managed the musculoskeletal manifestations in MPS patients [33,36]. Some clinical trials have started evaluating the efficacy of adalimumab [36]. Anti-TNF $\alpha$ can lead to clinical improvement in MPS patients and interfere with the mechanism behind the joint and bone disease that was not managed adequately with ERT. In the future, giving anti-TNF $\alpha$ along with ERT in MPS patients can lead to better consequences, since ERT alone had a limited impact on some organs.

Pentosan polysulfate, an anti-inflammatory drug that has a pro-chondrogenic effect, was used in MPS I and could improve both pain and joint mobility [37]. More clinical studies in the future should be conducted to look for other additional benefits of pentosan polysulfate, compare it with anti-TNF $\alpha$, and demonstrate whether its impact differs from one MPS type to another. Gene therapy, which can be a permanent therapy for MPS patients, is also promising and is currently under investigation by some studies that have not been completed yet [38,39].

When more studies in the future present enough evidence and explore additional impacts of these therapeutic agents, they can improve the quality of life in MPS patients a lot and make them less likely to undergo surgeries. Also, if they would be candidates for surgeries, these new therapies may reduce the rate of anesthesiologic complications in particular airway problems.

\section{Limitations}

There were certain limitations that we encountered in our review. The data included in this article was limited to humans only. Only those articles that were published in English language were selected; therefore, some valuable articles from other languages could have been missed. Randomized control trials and prospective studies of anesthesia management were lacking, and as the studies included were small populated, we could not find large samples. There is limited evidence regarding the efficacy of the new therapeutic agents in MPS patients, and several clinical trials of these treatments are not completed. In addition, more research should be conducted to explore its impact on airway management.

\section{Conclusions}

MPS patients require surgical procedures multiple times during the progression of the disease. However, the involvement of multiple organs and tissues leads to both clinical and physical problems regarding airway obtaining during surgical procedures. Access to recently introduced techniques and the availability of a team with advanced expertise in MPS diseases can reduce the incidence of airway-related complications dramatically. The impact of the previous MPS therapies on the airway is controversial. New treatment choices have been explored recently. However, their efficacy and exact impacts on different body organs and tissues are still under investigation.

\section{Additional Information \\ Disclosures}

Conflicts of interest: In compliance with the ICMJE uniform disclosure form, all authors declare the following: Payment/services info: All authors have declared that no financial support was received from any organization for the submitted work. Financial relationships: All authors have declared that they have no financial relationships at present or within the previous three years with any organizations that might have an interest in the submitted work. Other relationships: All authors have declared that there are no 
other relationships or activities that could appear to have influenced the submitted work.

\section{References}

1. Hack HA, Walker RWM, Gardiner P: Anaesthetic implications of the changing management of patients with mucopolysaccharidosis. Anaesth Intensive Care. 2016, 44:660-668. 10.1177/0310057X1604400612

2. Khan SA, Peracha H, Ballhausen D, et al.: Epidemiology of mucopolysaccharidoses. Mol Genet Metab. 2017, 121:227-240. 10.1016/j.ymgme.2017.05.016

3. Muhlebach MS, Wooten W, Muenzer J: Respiratory manifestations in mucopolysaccharidoses. Paediatr Respir Rev. 2011, 12:133-8. 10.1016/j.prrv.2010.10.005

4. Muenzer J: Overview of the mucopolysaccharidoses. Rheumatology (Oxford). 2011, 50:4-12. 10.1093/rheumatology/ker394

5. Ingelmo PM, Parini R, Grimaldi M, et al.: Multidetector computed tomography (MDCT) for preoperative airway assessment in children with mucopolysaccharidoses. Minerva Anestesiol. 2011, 77:774-80.

6. Rigante D, Segni G: Cardiac structural involvement in mucopolysaccharidoses. Cardiology. 2002, 98:18-20. 10.1159/000064674

7. Mendelsohn NJ, Harmatz P, Bodamer O, et al.: Importance of surgical history in diagnosing mucopolysaccharidosis type II (Hunter syndrome): data from the Hunter Outcome Survey. Genet Med. 2010, 12:816-22. 10.1097/GIM.0b013e3181f6e74d

8. Arn P, Whitley C, Wraith JE, et al.: High rate of postoperative mortality in patients with mucopolysaccharidosis I: findings from the MPS I Registry. J Pediatr Surg. 2012, 47:477-84. 10.1016/j.jpedsurg.2011.09.042

9. Arn P, Wraith JE, Underhill L: Characterization of surgical procedures in patients with mucopolysaccharidosis type I: findings from the MPS I Registry. J Pediatr. 2009, 154:859-64. 10.1016/j.jpeds.2008.12.024

10. White KK: Orthopaedic aspects of mucopolysaccharidoses. Rheumatology (Oxford). 2011, 50:26-33. 10.1093/rheumatology/ker393

11. Frawley G, Fuenzalida D, Donath S, Yaplito-Lee J, Peters H: A retrospective audit of anesthetic techniques and complications in children with mucopolysaccharidoses. Paediatr Anaesth. 2012, 22:737-44. 10.1111/j.1460-9592.2012.03825.x

12. Walker RWM, Darowski M, Morris P, Wraith JE: Anaesthesia and mucopolysaccharidoses. A review of airway problems in children. Anaesthesia. 1994, 49:1078-84. 10.1111/j.1365-2044.1994.tb04360.x

13. Muhlebach MS, Shaffer CB, Georges L, Abode k, Muenzer J: Bronchoscopy and airway management in patients with mucopolysaccharidoses (MPS). Pediatr Pulmonol. 2013, 48:601-7. 10.1002/ppul.22629

14. Moores C, Rogers JG, McKenzie IM, Brown TCK: Anaesthesia for children with mucopolysaccharidoses . Anaesth Intensive Care. 1996, 24:459-63. 10.1177/0310057X9602400408

15. Megens JHAM, De Wit M, Van Hasselt PM, Boelens JJ, Van der Werff DBM, De Graaff JC: Perioperative complications in patients diagnosed with mucopolysaccharidosis and the impact of enzyme replacement therapy followed by hematopoietic stem cell transplantation at early age. Paediatr Anaesth. 2014, 24:521-7. 10.1111/pan.12370

16. Clark BM, Sprung J, Weingarten TN, Warner ME: Airway management changes in patients with mucopolysaccharidoses: the role of video laryngoscopy. Can J Anaesth. 2017, 64:981-982. 10.1007/s12630017-0906-0

17. Scaravilli V, Zanella A, Ciceri V, et al.: Safety of anesthesia for children with mucopolysaccharidoses: A retrospective analysis of 54 patients. Paediatr Anaesth. 2018, 28:436-442. 10.1111/pan.13379

18. Madoff LU, Kordun A, Cravero JP: Airway management in patients with mucopolysaccharidoses: The progression toward difficult intubation. Paediatr Anaesth. 2019, 29:620-627. 10.1111/pan.13640

19. Cohen MA, Stuart GM: Delivery of anesthesia for children with mucopolysaccharidosis type III (Sanfilippo syndrome): a review of 86 anesthetics. Paediatr Anaesth. 2017, 27:363-369. 10.1111/pan.13075

20. Kamata M, McKee C, Truxal KV, et al.: General anesthesia with a native airway for patients with mucopolysaccharidosis type III. Paediatr Anaesth. 2017, 27:370-376. 10.1111/pan.13108

21. Kadic L, Driessen JJ: General anaesthesia in an adult patient with Morquio syndrome with emphasis on airway issues. Bosn J Basic Med Sci. 2012, 12:130-3. 10.17305/bibms.2012.2513

22. McLaughlin AM, Farooq M, Donnelly MB, Foley K: Anaesthetic considerations of adults with Morquio's syndrome - a case report. BMC Anesthesiol. 2010, 10:2. 10.1186/1471-2253-10-2

23. Caponas G: Intubating laryngeal mask airway. Anaesth Intensive Care. 2002, 30:551-69. 10.1177/0310057X0203000503

24. Michalek P, Hodgkinson P, Donaldson W: Fiberoptic intubation through an I-gel supraglottic airway in two patients with predicted difficult airway and intellectual disability. Anesth Analg. 2008, 106:1501-4. 10.1213/ane.0b013e31816f22f6

25. Dhanger S, Adinarayanan S, Vinayagam S, Kumar MP: I-gel assisted fiberoptic intubation in a child with Morquio's syndrome. Saudi J Anaesth. 2015, 9:217-219. 10.4103/1658-354X.152893

26. Jackson KM, Cook TM: Evaluation of four airway training manikins as patient simulators for the insertion of eight types of supraglottic airway devices. Anaesthesia. 2007, 62:388-93. 10.1111/j.1365-2044.2007.04983.x

27. Sayilgan C, Yuceyar L, Akbas S, Erolcay H: Anesthesia in a child with Maroteaux-Lamy syndrome undergoing mitral valve replacement. Clinics (Sao Paulo). 2012, 67:693-6. 10.6061/clinics/2012(06)26

28. Tsuchiya M, Terai H, Mizutani K, et al.: General anesthesia management for adult mucopolysaccharidosis patients undergoing major spine surgery. Med Princ Pract. 2019, 28:581-585. 10.1159/000503051

29. Berger KI, Fagondes SC, Giugliani R, et al.: Respiratory and sleep disorders in mucopolysaccharidosis. J Inherit Metab Dis. 2013, 36:201-10. 10.1007/s10545-012-9555-1

30. Solanki GA, Alden TD, Burton BK, et al.: A multinational, multidisciplinary consensus for the diagnosis and management of spinal cord compression among patients with mucopolysaccharidosis VI. Mol Genet Metab. 2012, 107:15-24. 10.1016/j.ymgme.2012.07.018

31. Caplan RA, Benumof JL, Berry FA, et al.: Practice guidelines for management of the difficult airway: an 


\section{Cureus}

updated report by the american society of anesthesiologists task force on management of the difficult airway. Anesthesiology 5. 2003, 98:1269-1277.

32. Kirkpatrick K, Ellwood J, Walker RWM: Mucopolysaccharidosis type I (Hurler syndrome) and anesthesia: the impact of bone marrow transplantation, enzyme replacement therapy, and fiberoptic intubation on airway management. Paediatr Anaesth. 2012, 22:745-51. 10.1111/j.1460-9592.2012.03897.x

33. Fecarotta S, Gasperini S, Parenti G: New treatments for the mucopolysaccharidoses: from pathophysiology to therapy. Ital J Pediatr. 2018, 44:124. 10.1186/s13052-018-0564-z

34. Settembre C, Fraldi A, Medina DL, Ballabio A: Signals from the lysosome: a control centre for cellular clearance and energy metabolism. Nat Rev Mol Cell Biol. 2013, 14:283-96. 10.1038/nrm3565

35. Marucha J, Tylki-Szymańska A, Jakóbkiewicz-Banecka J, et al.: Improvement in the range of joint motion in seven patients with mucopolysaccharidosis type II during experimental gene expression-targeted isoflavone therapy (GET IT). Am J Med Genet A. 2011, 155:2257-62. 10.1002/ajmg.a.34146

36. Effects of adalimumab in mucopolysaccharidosis types I, II and VI . (2015). Accessed: July 20, 2020: https://clinicaltrials.gov/ct2/show/NCT02437253.

37. Hennermann JB, Gökce S, Solyom A, Mengel E, Schuchman EH, Simonaro CM: Treatment with pentosan polysulphate in patients with MPS I: results from an open label, randomized, monocentric phase II study. J Inherit Metab Dis. 2016, 39:831-837. 10.1007/s10545-016-9974-5

38. Phase I/II gene transfer clinical trial of scAAV9.U1a.hSGSH . (2016). Accessed: July 20, 2020: https://clinicaltrials.gov/ct2/show/NCT02716246?term=Abeona.

39. Gene therapy in patients with mucopolysaccharidosis disease . (2017). Accessed: July 25, 2020: https://clinicaltrials.gov/ct2/show/NCT03173521?term=tigem. 